\title{
How to Apply Metacognitive Strategies in Collaborative Learning Setting?
}

\author{
Muntazhimah $^{1}$, Turmudi ${ }^{2}$, S Prabawanto $^{3}$ \\ \{muntazhimah@uhamka.ac.id ${ }^{1}$, turmudi@upi.edu ${ }^{2}$, sufyani@upi.edu ${ }^{3}$ \} \\ Universitas Prof. Dr. Hamka, Jl. Tanah Baru, Pasar Rebo, Jakarta Timur ${ }^{1}$, Universitas Pendidikan \\ Indonesia, Jl. Setia Budi, Bandung 2,3
}

\begin{abstract}
Many study explained that one of the ways to enhance student's mathematics ability is by giving them mathematics learning which could encourage to control the cognitive processes that they have. The alternative is could be metacognitive strategy. By metacognitive strategy, students are guided to be able to realize what they know and don't know in order to resolve the problem. Metacognitive strategy could be apply in collaborative learning settings in which collaboration is also one of the competencies in 21 st century skills. This study aims to explain the applying of metacognitive strategy in collaborative learning setting by preliminary and literature study. Using metacognitive in collaborative learning will increase mathematics ability because it foster confidence and awareness of mathematics concepts and principles learned and control the thought processes carried out .The impact is the metacognitive strategies could be applied in collaborative learning settings in order to enhance student's mathematics ability.
\end{abstract}

Keywords: Metacognitive Strategy, Collaboration Learning

\section{Introduction}

Mathematics is a universal study that is useful for human life and underlies the development of modern technology, and plays an important role in various disciplines and advancing human thought power. The purpose of learning mathematics is not only mastery of mathematics as a science, but also to understand the world around it and to succeed in life or career [1]. Mathematical skills according to Soedjadi are developing good reasoning, personality, and attitude, in addition to developing intelligence [2].

Mathematical skills will be trained as well as mathematical abilities of students. Research results show that the mathematical abilities of students in Indonesia are still low. A survey of the PISA (Program for International Student Assessment) conducted by the Organization for Economic Cooperation and Development (OECD) for 15-year-old children in 2015, placed the mathematical abilities of Indonesian students in $63^{\text {rd }}$ out of 72 countries [3]. Relatively similar results were shown from a research done by the Ministry of Education and Culture through the 2016 Indonesia National Assessment Program (INAP) that the mathematical ability of elementary school students is Around $77.13 \%$ of elementary school students throughout Indonesia had very low mathematical competence (low), $20.58 \%$ are sufficient and only $2.29 \%$ are categorized as good [4]. The latest RISE (Research on improvement of System Education) study in 2018 also showed the results that the ability of students to solve simple math problems is not significantly different between students who just entered elementary school and the 
students who have graduated from high school [5]. This signifies that students' mathematical abilities do not develop with increasing school level.

On the other hand, many studies conducted in order to improve students' mathematical abilities. Some studies showed that one of them is by providing mathematics learning that can encourage students to control the cognitive processes they possess [6] [7]. For instance, the ability to solve mathematical problems can be improved by metacognitive strategies that control the thought process during problem solving activities [8]. Furthermore, Toit and Kotze stated that metacognitive strategy is one of effective learning to help students learn mathematics effectively [9].

There have been many research related to metacognitive conducted. However, this research tries to provide a different touch. The researcher tried to modify the metacognitive strategy with a new issue in education, namely The Partnership for $21^{\text {st }}$ Century Skills. To pursue life and success in the future according to The Partnership for 21 st Century Skills requires a number of strategic skills, including learning skills, one of which is collaboration [10]. Therefore, this article was aimed at explaining how to apply metacognitive strategies in collaborative learning settings.

\section{Research Method}

This research is a library research preceded by a preliminary study to find the problems. There were several stages followed by the researcher. The first stage is gathering information from relevant sources to find problems, research ideas and new knowledge to be studied. The second stage is identifying and exploring things related to the topics that will be studied in depth. The third stage is building a relationship between the information found with the need to make a solution of the problem to be solved.

\section{Result and Discussion}

The following will describe the results of the study obtained from the preliminary studies and literature studies conducted previously.

\subsection{Result}

Metacognition refers to students' awareness of their abilities to understand, control, and manipulate the cognitive processes they have. Students are guided to be able to realize what they know and what they do not know and how they think about the problems being faced in order to be solved. Huitt stated that metacognition includes the ability to ask and answer questions such as, what do I know about this topic? Do I know what I need to know? Do I know where I get the information I need? What strategies and tactics can be used? And so on [11].

Therefore, learning with a metacognitive approach designs learning integrating metacognitive questions related to the topic being learnt as well as controlling to the thinking process. Metacognitive questions are integrated into teaching materials in writing and or directly through the verbal to foster confidence and awareness towards mathematical concepts and principles learned and control to the thinking processes. 
After conducting a preliminary research related to the use of metacognitive learning in mathematics learning, the researcher found that there were problems where the students stopped learning and gave up when they did not find the expected solution. Apparently this is also in line with Prabawanto's research showing that metacognitive learning still has weaknesses, for example, students will be confused and maybe stop learning when they do not understand or cannot find a solution for a mathematical problem that is being faced [12]. Alzahrani in his research also found that learning mathematics with metacognitive strategies requires at least two things, active participation of students in the search and discovery of knowledge and feedback from their friends [7] feedback from their friends is more effective than feedback given by the teachers or instructors [13]

The findings from the preliminary study lead to an assumption that it is necessary to modify the metacognitive strategies in learning so that the result is better and more effective. The modification is expected to be suitable with the needs of students in the future, the need to be able to survive and succeed in the future in accordance with the challenges. In education, The Partnership for $21^{\text {st }}$ Century Skills has developed a Framework for $21^{\text {st }}$ Century Learning that describes future competencies or $21^{\text {st }}$ century competencies $\left(21^{\text {st }}\right.$ century skills $)$ and a support system for developing $21^{\text {st }}$ century competencies $\left(21^{\text {st }}\right.$ century skills support systems). To live and succeed in the future according to The Partnership for $21^{\text {st }}$ Century Skills requires a number of strategic achievements, namely life skills, learning and innovation skills, and mastery of information technology. Learning and innovation skills (learning and innovation skills) consist of critical thinking, communication, collaboration, and creativity.

Collaboration is a skill needed by students to face their future, becoming an idea to modify metacognitive learning with collaborative learning that can facilitate students to interact and get feedback from peers. Collaborative Learning was presented by Gokhale. According to him "collaborative learning fosters critical thinking development through discussion, ideas clarification, and evaluation of other's ideas". [14]. In addition, Sato believes that collaborative learning is learning carried out in groups, but the aim is not to achieve the unity that is obtained through group activities. Students in groups are encouraged to find a variety of opinions or thoughts issued by each individual in the group [15]. Learning does not occur in unity, but learning is the result of diversity or difference. Collaborative learning refers to a method of learning with students of different performance levels working together in a small group. Wiersema states that "Collaborative Learning is philosophy: working together, building together, learning together, changing together, improving together" [16] while Le, Jeroen Janssen \& Theo Wubbels states that " Collaborative learning (CL) can be defined as a set of teaching and learning strategies promoting student collaboration in small groups (two to five students) in order to optimise their own and each other's learning"[17].

From several definition stated above, it can be concluded that the collaborative learning model is a group learning model where students with different levels of performance are encouraged to interact and learn together to improve their understanding and find new knowledge. The forms of interaction are discussion, asking questions and expressing opinions.

Reid [18] develops syntax in collaborative learning, namely: 1. Engagement, At this stage, the teacher evaluates the abilities, interests, talents and intelligence possessed by each student. Then, students are grouped in which there are smartest students, medium students and lowachieving students; 2. Exploration, after grouping, the instructor starts giving assignments, for example by giving problems to be solved by all groups. With the problems obtained, all group members must try to contribute their abilities in the form of knowledge, opinions or ideas; 3 . Transformation, from the different abilities possessed by each student, then each member exchanges ideas and conducts group discussions. That way, students who originally had low 
achievement, will eventually be able to increase their achievements because of the transformation process from students who have high achievements to students whose achievements are low; 4. Presentation, after completing the discussion and compiling the report, then each group presents the results of the discussion. When one group does an achievement, the other group watches, observes, compares the results of the presentation and responds; 5 . Reflection, after completing the presentation, a question and answer process occurs between groups. The group making the presentation will receive questions, responses or rebuttal from other groups. With questions raised by other groups, group members must work together in a compact way to respond properly.

Metacognitive strategies in collaborative learning settings, hereinafter referred to as MSC Learning, are modifications of the collaborative learning model that are combined with metacognitive strategies. Learning is carried out in groups with a heterogeneous level of performance, where students in groups are encouraged to find a variety of opinions or thoughts issued by each individual in the group, contribute to each other's thoughts and are responsible for achieving learning outcomes in groups and individually. MSC Learning also facilitates students to realize and monitor their abilities and the ability to understand, control, and manipulate the cognitive processes they have through questions such as, what do I know about this topic ?, Do I know what I need to know? Do I know where I get the information I need? What strategies and tactics can be used? And so forth. The metacognitive steps are broken down into the syntax of collaborative learning, namely: Engagement, Exploration, Transformation, Presentation, and Reflection. To be clear, look below at figure 1 about a syntax overview of MSC Learning.

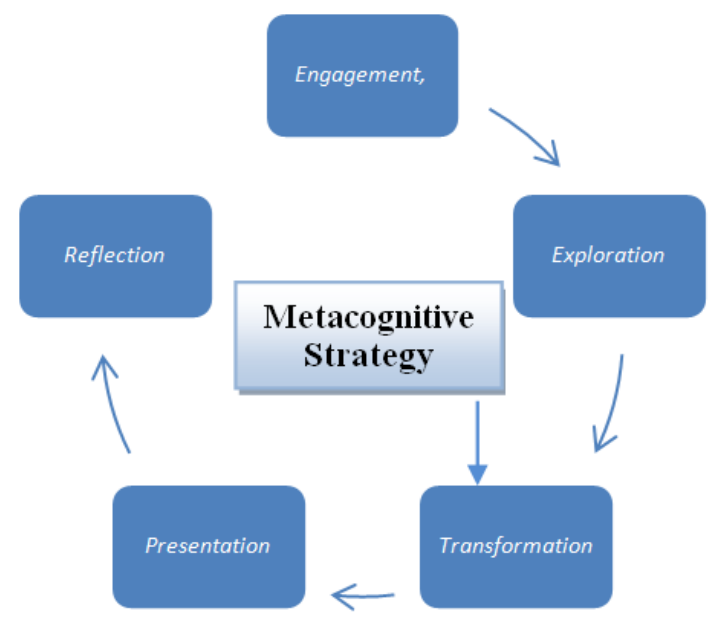

Fig. 1. The syntax of MSC learning.

\subsection{Discussion}

The results of Vygotsky's research prove that when students are given an assignment for themselves, they will work their best when working together or collaborating with friends. Vigotsky is one of the initiators of the social constructivism theory. This expert is well known for the "Zone of Proximal Development" or ZPD theory. The term "Proximal" used here can 
mean "next". According to Vygotsky, every human being (in this case is students) has a certain potential. This potential can be actualized by applying mastery learning. However, among the potential and actualization of students there is a gray area. The teacher has the obligation to make the "gray" area of the students actualized by means of group learning.

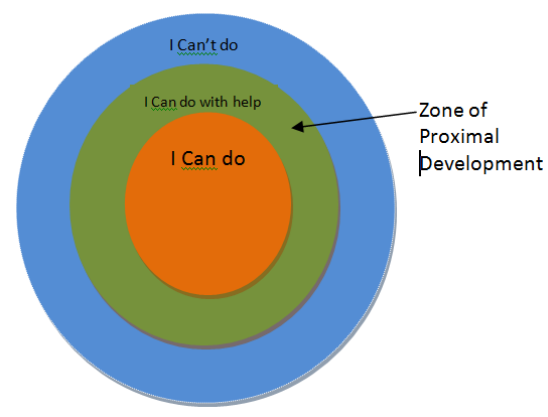

Fig. 2. Students` ability with ZPD area

As contained in the picture, Vygostsky put forward three areas covered in ZPD called "I cannot yet do", "I can do with help", and "I can do alone". ZPD is an area of "I can do with help" that is not permanent, if the learning process is able to attract students from the zone by way of collaboration or collaborative learning. Whereas the application of metacognitive strategies in learning through the answers to what questions I know about this topic? Do I know what I need to know? Do I know where I get the information I need? What strategies and tactics can be used? And other, allows students to have an awareness of their abilities and the ability to understand, control, and manipulate the cognitive processes that they have so that the problems being faced in order to be solved.

MSC Learning belongs to student-centered active learning. During the learning, students must be more active in the search for knowledge. In collaborative situations, students interact with others or teachers with empathy, mutual respect, and accept each other's weaknesses or strengths. So that will grow a sense of security, and allow students to face various changes and demands of learning together and control of cognitive processes so that it is expected to obtain more effective learning outcomes. The following is a cognitive description of students before and after learning with MSC Learning.
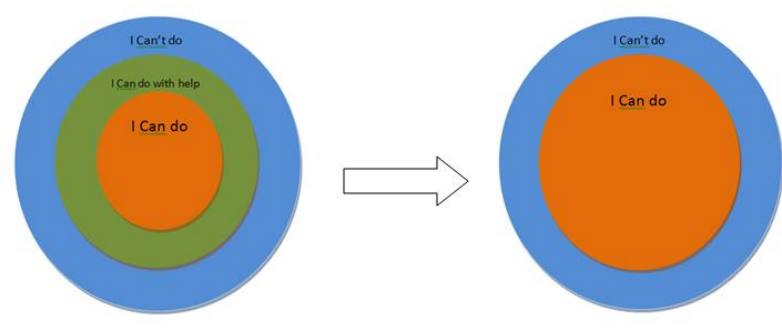

Fig. 3. Students' ability after applying MSC learning.

It can be seen from picture that students can go beyond their gray zone and change it to the "I Can do" zone after learning with MSC Learning. MSC Learning helps students to do all the 
tasks and solve the mathematics problems with metacognitive strategies and make collaboration with friends. MSC Learning also facilitates one of the $21^{\text {st }}$ Century skills, collaboration in learning which includes : having the ability to work in groups, adapt to various roles and responsibilities, work productively with others, have empathy and respect different perspective, be able to compromise with other members, in order to achieve the goals set[19].

\section{Conclusion}

The basis, function and objectives of national education are basically strong capital the Indonesian nation in facing the challenges of the 21 st Century. Specifically in terms of learning, it is necessary to strengthen and increase the competence of teachers in carrying out learning, especially learning that can answer the challenges of the 21 st Century. Learning must be able to encourage students to think critically and solve problems, communicative, creative, innovative, and collaborative, and mastering literacy, so they have higher-order thinking skills (HOTS).

Collaborative learning is one of learning that encourages students to have collaborative skills in accordance with 21 st century skills. On the other hand, metacognitive strategies encourage students to have higher-order thinking skills (HOTS). The impact is the metacognitive strategies could be applied in collaborative learning settings in order to enhance student's mathematics abilities. MSC Learning is an appropriate learning to be applied in learning that answers the challenges of the 21 st century.

Acknowledgments. The writer wants to thank the mathematics education lecturers at Post Graduate School of Universitas Pendidikan Indonesia who have provided insight into the constraints that the writer faced during the research conduct.

\section{References}

[1] Kementerian pendidikan dan Kebudayaan. Permendikbud N0. 58 tahun 2014 tentang pedoman

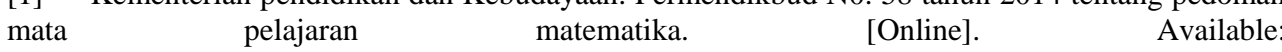
http://dikdasmen.kemdikbud.go.id/index.php/permendikbud-105-tahun-2014/ . [10 September 2019].

[2] R. Soedjadi. Kiat Pendidikan Matematika di Indonesia (Konstatasi Keadaan Masa Kini Menuju Harapan Masa Depan). Jakarta: Ditjen Dikti Depdikbud. 1999

[3] [Online]. Available: https://www.oecd.org/pisa/PISA-2015-Indonesia.pdf. [11 September 2019]

[4] Kementerian Pendidikan dan Kebudayaan, Balitbang-Pusat Penilaian Pendidikan. [Online].

Available: https://puspendik.kemdikbud.go.id/inap-sd/. [13 September 2019]

[5] Amanda Beatty, Emilie Berkhout, Luhur Bima, Menno Pradhan, Daniel Suryadarma.: Indonesia got schooled : 15 years of rising enrolment and flat learning profiles. [Online]. Available : https://www.riseprogramme.org/publications/rise-working-paper-18026-indonesia-got-schooled-15years-rising-enrolment-and-flat. [13 September 2019]

[6] Grant, G.: A metacognitive-based tutoring program to improve mathematical abilities of rural high school students: An action research study. (Ph.D), Capella University. 2014

[7] Khalid S. Alzahrani.: Metacognition and Its Role in Mathematics Learning: an Exploration of the Perceptions of a Teacher and Students in a Secondary School. International Electric Journal of Mathematics education, 12(3), pp. 521-537. 2017. [Online]. Available: https://www.iejme.com/download/metacognition-and-its-role-in-mathematics-learning-anexploration-of-the-perceptions-of-a-teacher.pdf. [15 September 2019] 
[8] Özsoy, G., \& Ataman, A.: The effect of metacognitive strategy training on mathematical problem solving achievement. International Electronic Journal Of Elementary Education, 1(2), pp. 67-82. [Online]. Available: https://www.iejee.com/index.php/IEJEE/article/view/278. 2017. [16 September 2019]

[9] Stepan Du Toit, Gary Kotze.: Metacognitive strategies in the teaching and learning of mathematics.Pythagoras.70. pp. 57-67. 2009. [Online]. Available : https://www.researchgate.net/publication/271303405_Metacognitive_strategies_in_the_teaching_and _learning_of_mathematics. [16 September 2019]

[10] Ministry of Education Singapore. 21st Century Competencies. 2015. [Online]. Available: https://www.moe.gov.sg/education/educationsystem/21st-century-competencies. [16 September 2019]

[11] Hewitt, D.: Understanding effective learning, strategies for the classroom. London: Mc Graw Hill.2008

[12] Prabawanto, S.: The enhancement of students' mathematical selfefficacy through teaching with metacognitive scaffolding approach. IOP Conf. Series: Journal of Physics: Conf. Series. Vol.1013, 2018

[13] Mutekwe, E.: Unpacking Student Feedback as a Basis for Metacognition and Mediated Learning Experiences: A Socio-cultural perspective. Journal of Education and Learning (EduLearn), 8(4), pp. 338-348. 2014

[14] Gokhale, A. A.: Collaborative Learning Enhances Critical Thinking. Journal of Technology Education, 7(1). 1995. [Online]. Available : http://scholar.lib.vt.edu/ejournals/JTE/v7n1/gokhale.jtev7n1.html. [17 September 2019]

[15] Sato, M.: Mereformasi Sekolah. Tokyo: International Development Center of Japan Inc. 2013 [16] Wiersema, N.: How Does Collaborative Learning Actually Work in a Classroom and How Do Students React to It? 2000. [Online]. Available : www.city.londonmet. ac.uk/deliberations/collab.learning/wiersema.html. [17 Septembet 2019]

[17] Ha Le, Jeroen Janssen \& Theo Wubbels.: Collaborative learning practices: teacher and student perceived obstacles to effective student collaboration, Cambridge Journal of Education, 48:1, pp. 103122. 2018.

[18] Reid.: Enhancing student thingking through collaboration learning. 2004. [Online]. Available : http://www.ed.gov/database/ERIC_Digest/. [17 September 2019]

[19] Direktorat Pembinaan SMA. Dirjen pendidikan dasar dan menengah. Kementerian pendidikan dan Kebudayaan. Panduan Implementasi Kecakapan Abad 21Kurikulum 2013 di Sekolah Menengah Atas. 2017 